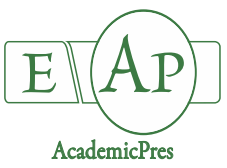

Abd El Baky $\mathrm{H}$ and El Baroty GS (2020)

Notulae Botanicae Horti Agrobotanici Cluj-Napoca 48(3):1439-1457

DOI: $10.15835 / 48311803$

Research Article

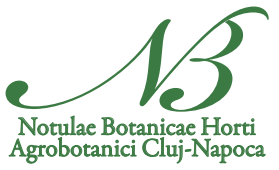

\title{
Optimization cultivation of Chlamydomonas reinhardtii in a tubular photobioreactor (2000 Liter) for biomass and green bioenergy (biodiesel) production
}

\author{
Hanaa H. ABD EL BAKY', Gamal S. EL BAROTY²* \\ ${ }^{1}$ National Research Centre, Plant Biochemistry Department, Dokki, Cairo,12026,Egypt; abdelbakyh@hotmail.com \\ ${ }^{2}$ Cairo University, Faculty of Agriculture, Department of Biochemistry, Cairo, \\ Egypt; elbarotys@hotmail.com (" ${ }^{*}$ corresponding author)
}

\begin{abstract}
The biodiesel can be produced from diverse microalgae lipids as alternative and renewable fuel. Thus, the aim of this study was to optimize the Chlamydomonas reinhardtii promising species as biodiesel feedstock for large-scale cultivation in Egypt. To understand some of the triggers required for the metabolic pathway switch to lipid accumulation, the effect of carbon sources and the three elements availability $(\mathrm{N}, \mathrm{P}, \mathrm{S})$ in $C$. reinhardtiigrowth medium was determined. A local microalgae C. reinhardtii was cultured in modified Sueoka medium containing various concentrations of $\mathrm{CO}_{2}$ and bicarbonate $\left(\mathrm{NaHCO}_{3}\right)$ (in 2-liter flasks) as a carbon source. The optimal source in term biomass, high lipid productivity $\left(10.3 \mathrm{mgL}^{-1} \mathrm{~d}^{-1}\right)$ and a higher lipid content $(22.76 \%)$ were obtained in $6 \% \mathrm{CO}_{2}$ culture. Then, the availability of $\mathrm{N}, \mathrm{P}, \mathrm{S}$ (various concentrations of $\mathrm{N}, \mathrm{P}$ and S) nutrients elements was added to $6 \% \mathrm{CO}_{2}$ culture, for produce a highest lipid content and lipid productivity. As expected, under low availability N-1.78 mM; P- $0.14 \mathrm{mM}$ and S- $0.10 \mathrm{mM}$ mediums, $C$. reinhardtii showed a high accumulation lipid content. Therefore, to improve the economic feasibility of microalgae biofuels production, its concentrations were selected to combine $(\mathrm{N}+\mathrm{P}+\mathrm{S})$ in order to cultivation of C. reinhardtii in a multi-tubular photobioreactor (400 liter) to produce high lipid contents. Under limited condition, the biomass dry weight, biomass productivity, lipid content and lipid productivity were found to be $3.11\left(\mathrm{gL}^{-1}\right), 0.15 \pm 0.012\left(\mathrm{~g}^{-1} \mathrm{~L}^{-1} \mathrm{~d}^{-1}\right), 22.76 \%(\mathrm{w} / \mathrm{w} \%)$ and $1.9 \pm 0.35\left(\mathrm{mg}^{-1} \mathrm{~L}^{-1} \mathrm{~d}^{-1}\right)$, respectively. The extracted lipid was found to have physical and chemical properties similar that plant oils using for biodiesel production. The FAME profiling of prepared biodiesel shows the presence of considerable amount of $36.97 \%$ saturated fatty acids (palmitic acid and stearic acid, together) with $27.33 \%$ unsaturated (oleic acid and linoleic acid) fatty acids. The FAME had a low iodine value and high $\mathrm{CN}$, which meet with the appropriate of biodiesel standards (EN 14214 and ASTM D6751). Thus, C. reinhardtii appears to be more feasible for high quality biodiesel production.
\end{abstract}

Keywords: biodiesel production; C. reinhardtii; lipids; photobioreactor

Received: 06 Feb 2020. Received in revised form: 08 Aug 2020. Accepted: 24 Aug 2020. Published online: 08 Sep 2020. 


\section{Introduction}

The extensive high usage of fossil fuels had a significant negatively impacted on global climate change. Therefore, to solve of these problems, could be by reduction of carbon emission, hydrocarbon $\left(\mathrm{HC} \mathrm{CH}_{4}\right)$, nitrogen oxides $\left(\mathrm{NO}_{\mathrm{x}}\right)$, carbon monoxide $(\mathrm{CO})$, particulate matter $(\mathrm{PM})$ and selected renewable biomass as alternative energy source (Singh et al., 2018; Goh et al., 2019). The biofuel derived from biomass are developed as an environmentally (characterizes by sulphur-free, nontoxic and biodegradable) and socially acceptable substitute for fossil fuels (Lee and Kim, 2017; Cesar et al., 2019). Recently, several strains of microorganisms rich in lipid contents (e.g., fungus, bacteria and microalgae) have been reported as ideal as an excellent feedstock for biofuel production (Abd El Baky and El Baroty, 2016; Patel et al., 2017). However, many factors such as nutrients stress (nitrogen, phosphorus, iron and salt); temperature, $\mathrm{pH}$, light intensity and photoperiod had a directly impact on biomass and lipid content of microalgae (Abd El Baky et al., 2012; Singh et al., 2015).

In general, a high quantity of lipid and high quality of the fatty acid compositions should be considered when seeking efficient biomasses for biofuel production. The fuel properties of biodiesel produced from feedstocks significantly depend on the fatty acids compositions. In this trend, the main compositions of the lipid of microalgae are containing unsaturated fatty acids, especially palmitolleic (16:1), oleic (18:1) and linoleic (18:2) and the saturated fatty acids of palmitic (16:0) (Sajjadi et al., 2018). The ideal biodiesel 16:0 and C18:1 fatty acid methyl esters (FAMEs/) with high biodiesel conversion is produced via the trans-esterification reaction of lipids and short-chain alcohols with appropriate homogeneous catalysts (e.g. sodium hydroxide, sulphuric acid etc.) (Singh et al., 2015; Patel et al., 2017). Thus, the microalgae have been proved as promising candidates for large-scale biodiesel production. That have high photosynthesis efficiency, fast and short growth cycle (can be double their biomass weight within $24 \mathrm{~h}$ ), high lipid content, and no culturing land and can be grown in wastewater or in seawater (Ma et al., 2018; Sun et al., 2018).

The biodiesel production is still challenging towards a large-scale application of microalgae lipid, and is still a technical challenge due to low yields and commoditization of biotechnological products. The lipid accumulation of lipids in microalgae is essential to improve the commercial feasibility of biodiesel production (Singh et al., 2015). In order to increase the biomass productivity, the high-density culture of microalgae had been carried out in photobioreactors (airlift tubular and bubble column) with minimal nutrients (for large scale cultivation), high illumination surfaces and high biomass transfer rates (Fan et al., 2008). The cultivation of microalgae in open or closed photobioreactor (PBR) systems, that can be controlled by operating parameters leading to higher productivities and improve its performance (Martins et al., 2018). However, the biochemical characteristic parameter and harvesting yield of microalgae biomass culture in PBRs have not been extensively investigated (Lam and Lee, 2014). In previous work, we demonstrated that some microalgae species can grow much faster in the tubular photobioreactor with high biomass productivity and high lipid contents (Abd El Baky and El Baroty, 2016). Generally, the lipid productivity could be enhanced by nutrient stress to increases the lipid content of microalgae (Fan et al., 2008; Abd El Baky and El Baroty, 2016). In response to various cultivation conditions, metabolic pathway of algae cells could be change toward lipid accumulation, thereby increase the enzyme activity of acetyl-CoA carboxylase a key enzyme in fatty acid biosynthesis (Karpagam et al., 2015). A strategy to gained a lipid high-yielding from microalgae through nutrient limitation conditions (i.e., nitrogen deprivation, iron starvation and phosphorus depletion) and specific growth environment condition (stimuli high light or osmotic stress) were determined (Benvenuti et al., 2015; Karpagam et al., 2015; Zhang et al., 2019). Under limited condition, lipid accumulation can be optimized by selecting a suitable microalgae species and manipulating the initial fatty acid profile by varying the growth conditions for largescale production, which can be used as a source of biodiesel (Abd El Baky et al., 2014). In the green algae Chlamydomonas reinhardtii accumulates increased quantity of lipids under conditions of macro- or micro nutrient depletion such as sulfur, nitrogen, phosphorus and iron or in physical stresses conditions, e.g. temperature, pH, salinity and high light (Kropat et al., 2011; Benvenuti et al., 2015; Wang et al., 2018). 
This study aimed to find suitable carbon source (gaseous $\mathrm{CO}_{2}$ or bicarbonate) and nutrient availability (nitrogen $\mathrm{N}$, phosphor $\mathrm{P}$ and sulfur $\mathrm{S}$ ) levels for cultivating a $C$. reinhardtii strain (isolated from a freshwater reservoir in Egypt), to optimize lipid productivity. To enable economic production of algal biodiesel, the individual concentration $\mathrm{P}, \mathrm{S}$ and $\mathrm{N}$ produces a high lipid yield, were selected for cultivation of $C$. reinhardtii in combined nutrients $(\mathrm{P}+\mathrm{S}+\mathrm{N})$ at large scales in a bubble column photobioreactor that (2000 Liter) to maximizes the microalgae biomass and lipid productivities for biodiesel production. The FAME profiling and quality biodiesel of prepared were investigated.

\section{Materials and Methods}

\section{Reagent and chemicals}

All the chemicals and solvents were purchased from Sigma Aldrich and E. Merck CO. Other fine chemicals not mentioned here were of analytical grade and obtained from standard sources. The Millipore Milli Q plus system was used to prepare the high purely deionized water.

\section{Microalgae strain}

Microalga strain and pre-culture condition

Chlamydomonas reinhardtii strain was isolated from freshwater samples from the El Dokki region, Giza, Egypt), was preserved in a modified Sueoka (MS pH 7.0) medium under optimum conditions, as reported in a previous work (Kim et al., 2016). The pure strain had been deposited in Egyptian culture collection (accession number EMCCN 3043), National Research Centre (Giza, Egypt). For optimize the nutrient grown, employing different concentrations of $\left(\mathrm{CO}_{2}\right.$ and bicarbonate $)$ as a carbon sources, bicarbonate at 0.2 , 0.4 and $0.8 \mathrm{~g} \mathrm{~L}^{1}$ and $\mathrm{CO}_{2}$ enriched air supply 3, 6, $12 \%$ in two-liter Erlenmeyer flasks each containing $1800 \mathrm{~mL}$ of MS medium, was achieved, that to ensure the better results for accumulation high lipid contents. The $C$. reinhardtii strain was grown photo-autotrophically under 10 white florescent light lamps (Philips $40 \mathrm{~W}$ ) provided an illumination of 2500 lux. After the first steady-state condition was reached, $\mathrm{CO}_{2}$ at $6 \%$ as a carbon source was selected due to given higher biomass dry weight and biomass productivity, further treatments, by study the effect of the three elements availability $(\mathrm{N}, \mathrm{P}, \mathrm{S})$ in $C$. reinhardtiigrowth medium was determined to optimize and develop the economic viability of Chlamydomonas reinhardtii as feedstock biodiesel. Therefore, the $C$. reinhardtii was growing in different medium containing serial concentrations of nitrogen $(9,7.5,0.93$ $\mathrm{mM})$, phosphorus $(1.13,0.70,0.14 \mathrm{mM})$, sulfur $(0.43,0.25,0.1 \mathrm{mM})$ to enhance lipid yield and high lipid productivity. In all cultivated flasks, conductivity, salinity, $\mathrm{pH}$ and temperature were measured every two with Hanna (HI 09812-5) conductivity meter. The purity of cultures was periodically checked by microscopic observation following taxonomy guidelines.

\section{Cultivation of C. reinhardtii in 2000 L photobioreactor}

A C. reinhardtii was cultivated in 2000 liter (large scale) tubular photobioreactor (Figure 1) modified Sueoka medium containing a combination of limited three element (0.1 Sulfur, 7.0 Nitrogen and $0.43 \mathrm{mM}$ phosphorus, $\mathrm{S}+\mathrm{N}+\mathrm{P}$, is the most suitable nutrient levels for enhance lipid accumulation for biodiesel production (Sueoka et al., 1967). However, our designs, the photobioreactor (PBR) as showing in Fig. 1, which made of low-cost polypropylene-based (CPP) tubes, had high transparence and durability of the material. The working volume of these PBRs was $2000 \mathrm{~L}$ (8 tubes, with dimensions of $25 \mathrm{~cm}$ inner diameter, $6 \mathrm{~mm}$ wall thickness, and $2 \mathrm{~m}$ height to provide a total volume of 100 liter each). A 2 stone sparger was used to input gases into the PBRs, and 8 spargers for the serial-column connection. The base tube was mounted on a stainless-steel support stand. The PBR was continuously aerated by compressed-air from an air pump through the static sparger and air flow rate was controlled by a flow meter. The cultivation system was maintained at 24 -hour 
photo-period via ten cool-white fluorescent light (Philips, TL-D 36W/54-765) that was illuminated with an intensity of $60-70 \mu \mathrm{mol} \mathrm{m}^{-2} \mathrm{~s}^{-1}$.

\section{Harvesting}

At the end of each batch run (the experiment was repeated 3 times and average), cultures were collected, filtered, washed with distilled water to remove any residual soluble salts, centrifuged at $3000 \mathrm{xg}$ for $15 \mathrm{~min}$ at $4{ }^{\circ} \mathrm{C}$ and the pellets was frozen until using.

\section{Growth measurement}

The growth of $C$. reinhardtii was assessed every two days, during the 16 days of the cultivation period (log and stationary phase), using the dry cell weight method and optical density of the culture suspension. The optical density (OD) was read at $680 \mathrm{~nm}$, and the biomass density of the culture suspension was calculated. A standard curve was established by correlation of the absorbance values (OD 680) and dry cell weight $(\mathrm{g} / \mathrm{L})$ as follows: Dry weight g/L $=1.074 \mathrm{X} \mathrm{OD}_{680}+0.09855$.
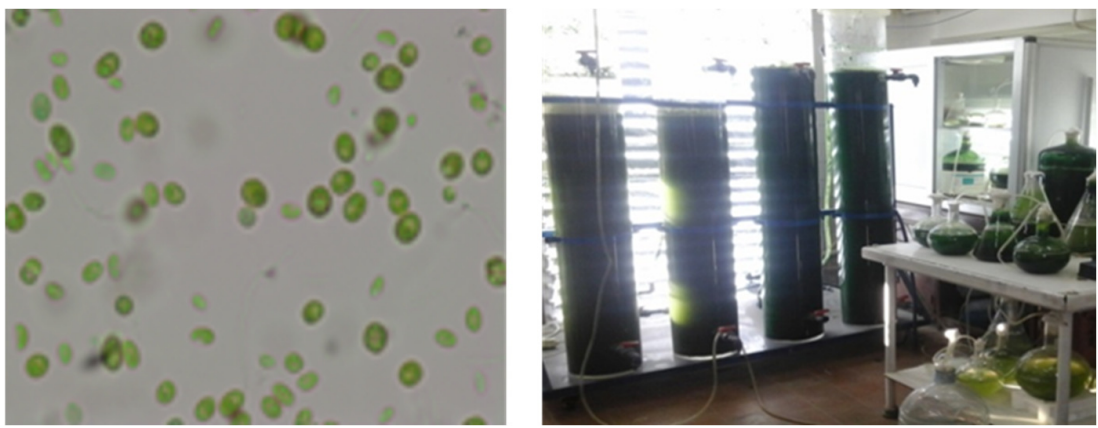

Figure 1. Chlamydomonas reinhardtiicells and large-scale cultivation in tubular photobioreactor

\section{Determination of dry cell weight}

To determine the dry cell weight, a known volume of $(10 \mathrm{ml})$ culture suspension was centrifuged at 3000 $\mathrm{x} g$ for $15 \mathrm{~min}$. The collected cells pellet was several times washed with distilled water to get rid of medium of any trace's nutrients. Then, the biomass pellet was dried in an oven at $60^{\circ} \mathrm{C}$ to get the constant weight and kept for further analysis.

\section{Microalgae growth parameters}

During the cultivation period, growth parameters were determined as follows:

\section{Biomass productivity $(\mathrm{PB})$}

The dry biomass produced $\left(\mathrm{gL}^{-1} \mathrm{day}^{-1}\right)$, during the stationary growth phase was determined. A known volume of the algal suspensions was centrifuged $(2000 \mathrm{x} \mathrm{g}, 15 \mathrm{~min})$ and the resulting pellets were washed with de ionized water, dried at $70{ }^{\circ} \mathrm{C}$ for $48 \mathrm{~h}$ and their dry weights were determined gravimetrically.

\section{Specific growth rate (SGR, $\mu \mathrm{g} /$ day)}

The specific growth rate (SGR $\mu \mathrm{g} /$ day) of $C$. reinhardtii culture was determined using the following equation: $\operatorname{SGR}(\mu \mathrm{g} /$ day $)=\ln \left(X_{1}-X_{2}\right) / t_{2}-t_{1}$ : Where, $X_{1}=$ Biomass concentration at the end of selected time interval, $X_{2}=$ biomass concentration at the beginning of selected time interval, and $t_{2}-t_{1}=$ elapsed time between selected time in the day. 


\section{Determination of total chlorophyll a (Chla)}

A known volume $(10 \mathrm{ml})$ from each culture was harvested by centrifuging, and then algal pellet was washed several times with distilled water and re-suspended in $10 \mathrm{ml}$ of $95 \%$ methanol. The tubes containing algal suspension were extracted aided by ultrasonic processor, centrifuged again to remove the cell debris. The supernatant containing the pigment was transferred to a volumetric flask $(10 \mathrm{ml})$ and volume was made up to $10 \mathrm{ml}$ by adding pure methanol. A blank with $100 \%$ methanol was run simultaneously. The Chl a content in the biomass was spectrophotometrically at $648.6 \mathrm{~nm}$ and $664.2 \mathrm{~nm}$ (Lichtenthaler 1983/7) using the follows Eq. Chl $A=\left(13.36 \mathrm{~A}_{664}-5.19 \mathrm{~A}_{648}\right) \times 8.1 /$ dry weight $(\mathrm{mg} / \mathrm{g} \mathrm{dw})$.

\section{Determination of total lipids contents}

To determine the total lipid content in dried algal cells $C$. reinhardtii, $2 \mathrm{~g}$ of biomass was extracted with $30 \mathrm{ml}$ hexane: methanol (v/v, 1:1) and then $3 \mathrm{ml}$ of distilled water was added. The contents were mixed for 10 $\mathrm{min}$ in a shaker, and then left at room temperature $25^{\circ} \mathrm{C}$ for $10 \mathrm{~min}$. The organic layer was separated by a 50 $\mathrm{ml}$ separating funnel, several times washed with $5 \% \mathrm{NaCl}$ solution. Then, the organic extract was evaporated under vacuum to smallest volume, and evaporated under nitrogen stream. The lipid yield of $C$. reinhardtii was calculated in percentage gravimetrically (\%).

Lipid productivity (LP)

Lipid productivity $\left(\mathrm{LP}, \mathrm{mgl}^{-1} \mathrm{day}^{-1}\right)$ of $C$. reinhardtii was calculated according to the Liu equation (Liu et al., 2011) LP $=1 / 4 \mathrm{~PB}-\mathrm{LC}$

\section{Determination of physical-chemical properties of C. reinhardtii lipid}

Based on AOCS official method (1998), acid value (AV, Ca 5a-40), saponification value (cd 3-25), iodine value (IV, Cd 1-25) and peroxide value (PV Cd 8-53) of algal lipids were determined. The molecular weight of the oil (M) was calculated from saponification and acid value according to $\mathrm{M}=168300 / \mathrm{SV}-\mathrm{AV}$ formula. The viscosity was measured with capillary viscometer in a constant temperature in bath at $40{ }^{\circ} \mathrm{C}$.

\section{Biodiesel preparation}

Biodiesel from algal lipids was derived by acidic trans-esterification method. Algae lipid was mixed with methanol with 1:56 ratio (weight ratio) and the reaction was carried out at $45^{\circ} \mathrm{C}$ for $4 \mathrm{~h}$ in the presence of sulfuric acid $\left(\mathrm{H}_{2} \mathrm{SO}_{4}\right)$ as catalyst with 1:1 weight ratio of catalyst to lipids. The upper biodiesel layer was separated by a separating funnel, washed several times with $5 \% \mathrm{NaCl}$ solution to remove any traces of methanol and glycerol. Then, the biodiesel was dried over anhydrous sodium sulfate and collected and evaporated at 45 ${ }^{\circ} \mathrm{C}$ to constant weight for analysis. The biodiesel yield from microalgae biomass was determined gravimetrically by the following equation: Biodiesel yields (\%) = [biodiesel mass (g) / algae mass (g) X lipid content \%] x 100\%

\section{Algal biodiesel fatty acid methyl ester profile by GC/MS}

The fatty acid methyl ester (FAME) composition of algal biodiesel was analyzed by using GC-MS. The GC-MS detection was performed with an HP-6890 gas chromatograph connected to an HP 5973 mass selective detector at $70 \mathrm{eV}\left(\mathrm{m} / \mathrm{z} 50-550 \mathrm{amu}\right.$; source at $230^{\circ} \mathrm{C}$ and quadruple at $\left.150^{\circ} \mathrm{C}\right)$ in the electron impact mode with a TR-FAME-ms ( $75 \%$ cyanophenyl-silxane (Thermo (USA) capillary column $(30 \mathrm{~m} \times 0.25 \mathrm{~mm}$ i.d., $0.25 \mu \mathrm{m}$ film thickness). The oven temperature was programmed for $2 \mathrm{~min}$ at $80^{\circ} \mathrm{C}$ and raised to $280^{\circ} \mathrm{C}$ at 4 ${ }^{\circ} \mathrm{C} / \mathrm{min}$ and maintained for $5 \mathrm{~min}$ at $280^{\circ} \mathrm{C}$. Helium was used as carrier gas (flow rate of $1.2 \mathrm{ml} / \mathrm{min}$ ). The inlet temperature was maintained at $300{ }^{\circ} \mathrm{C}$. Structural assignments were based on interpretation of mass spectrometry fragmentation (NIST $11 \mathrm{MS}$ spectra) and confirmed by comparison of retention times as well as fragmentation patterns of authentic standard FAMEs Mix (Supelco 37 Component FAME Mix, purity $>98.0 \%$ by GC, Sigma-Aldrich). 


\section{Characterization of properties of C. reinhardtii biodiesel}

The physical and chemical properties of $C$. reinhardtii biodiesel was evaluated based on ASTM biodiesel standard or AOCS methods. Physical and chemical characteristics include: density at $15^{\circ} \mathrm{C}$ (ASTM D4052), kinematic viscosity at $40{ }^{\circ} \mathrm{C}$ (ASTM D445), iodine value (AOCS 1998), acid value (ASTM D664), peroxide value (AOAC, 1999), saponification value. The other important biodiesel quality properties were determined mathematical following the empirical equations published by Ramos et al. (2009) and Wu and Miao (2014): cetane number (CN, 46.3+5458/SV- 0.225 IV), degree of un saturation /saturation (DU), longchain saturated factor (LCSF), and cold filter plugging point (CFPP). All determinations for biodiesel properties were conducted at least three times for each sample, and the results were averaged.

\section{Results and Discussion}

A Chlamydomonas reinhardtii green microalgae is grown in the laboratory for research in biofuels study's due to its fast growth rates and accumulate lipids. This study aimed to optimize the productivity of lipid content for biodiesel production. Thus, the carbon (sources and concentrations) and three elements availability $(\mathrm{N}, \mathrm{P}, \mathrm{S})$ in $C$. reinhardtii growth medium required for the metabolic pathway switch to lipid accumulation was determined. To achieve this $C$. ireinhardtii are cultured in different nutrient conditions continuously under laboratory scales (2-liter flasks) (Table 1 and Figure 2).

Table 1. Impact of carbon scours and concentrations on Chlamydomonas reinhardtii biomass

\begin{tabular}{|c|c|c|c|c|c|}
\hline \multicolumn{7}{|c|}{ Carbon scours and culture age (days) } \\
\hline Concentrations & \multicolumn{5}{|c|}{ Culture Age (days) } \\
\hline $\mathrm{CO}_{2}$ & 0 & 3 & 6 & 9 & 12 \\
\hline $3 \% \mathrm{CO}_{2}$ & 0.651 & 0.916 & 2.11 & 2.78 & 3.22 \\
\hline $6 \% \mathrm{CO}_{2}$ & 0.584 & 0.995 & 2.56 & 3.99 & 5.11 \\
\hline $9 \% \mathrm{CO}_{2}$ & 0.679 & 0.864 & 1.13 & 1.89 & 2.34 \\
\hline $\mathrm{NaHCO}_{3}$ & 0 & 3 & 6 & 9 & 12 \\
\hline $2.5 \mathrm{mmol} \mathrm{L}^{-1}$ & 0.611 & 0.854 & 1.99 & 2.68 & 3.75 \\
\hline $5.00 \mathrm{mmol} \mathrm{L}^{-1}$ & 0.634 & 0.915 & 2.89 & 3.86 & 4.32 \\
\hline $7.50 \mathrm{mmol} \mathrm{L}^{-1}$ & 0.656 & 0.851 & 1.89 & 2.96 & 3.43 \\
\hline
\end{tabular}

Firstly, C. ireinhardtii cultured in Sueoka medium containing optimal concentration of N, S and P and different concentrations of carbon sources (carbonate and $\mathrm{CO}_{2}$, as a rich $\mathrm{R}$, optimal $\mathrm{O}$ and limited $\mathrm{L}$ concentrations). The data of revealed that biomass yields (BM) and total lipid contents (TL) were significantly different $(\mathrm{P}>0.5 \%)$ among all tested cultures $\left(\mathrm{CO}_{2}\right.$ 3, 6, 12\%) and sodium bicarbonate salt 2.5, 5.0 and $\left.0.5 \mathrm{mmol} \mathrm{L}^{-1}\right)$. The biomass yields (as dw) were $2.9 \mathrm{~g} \mathrm{~L}^{-1}$ in $6 \% \mathrm{CO}_{2}\left(2.9 \mathrm{~g} \mathrm{~L}^{-1}\right)$ and $3.22 \mathrm{~g} \mathrm{~L}^{-1}$ in $3 \% \mathrm{CO}_{2}$ culture. Whereas, these values were $0.122,0.191$ and $0.201 \mathrm{mg} / \mathrm{L}$, respectively in cultures supplemented with $2.5,5.0$ and $7.50 \mathrm{mmol} \mathrm{L}^{-1} \mathrm{NaHCO}_{2}$. The lower yield of biomass in carbonate cultures suggests the occurrence of stress conditions induced by high bicarbonate levels in the medium due to excess osmotic pressure (Table 2 and Figure 2). However, after 12 days of cultivation, the highest oil content (\%) and oil yield were found to be (2.9 and $2.6 \mathrm{gd}^{-1} \mathrm{~L}^{-1}$ ), oil contents (20\% and $27 \%$, of dw.) and lipid productivity (32 and $36 \mathrm{mg} \mathrm{L}^{-1} \mathrm{~d}^{-1}$ ) were observed, respectively in $6 \%$ and $9 \%$ cultures. It is interesting to note that oil yield in $6 \% \mathrm{CO}_{2}$ culture was higher that obtained in $9 \% \mathrm{CO}_{2}$ culture. Moreover, higher lipid productivity of $C$. ireinhardtii cultures supplied of gaseous $\mathrm{CO}_{2}$ could be more economically sustainable than that supplied by an exogenous organic carbon source (Davey et al., 2014; Juergens, et al., 2016). Due to the high lipid productivity and lipid contents are considered as the most important desirable characteristic of chosen the microalgae strains to use for biodiesel production (Griffiths and Harrison, 2009), thus, $6.0 \%$ was used for as carbon source for further cultivation C. ireinhardtii to provide the best result in terms of higher oil yield and biomass. Quit similar concentration level were 
reported for cultured the M. pusillum O. multisporus, Dunaliella, chlorella and Spirullina cultured grown at 5\% $\mathrm{CO}_{2}$ (Tang et al., 2011; Abd El Baky et al., 2012, 2014).

Table 2. Impact of carbon scours and concentrations on Chlamydomonas reinhardtii oil content (\%) and oil yield

\begin{tabular}{|c|c|c|c|c|c|c|}
\hline \multicolumn{2}{|c|}{ Carbon scours and concentrations } & Culture Age (days) & \multicolumn{2}{|c|}{ Culture Age (days) } & \multicolumn{2}{c|}{$\begin{array}{c}\text { Oil yield } \\
\mathrm{mg} / \mathrm{L}\end{array}$} \\
\hline $\mathrm{CO}_{2}$ & 0 & 3 & 6 & 9 & 12 & \\
\hline $3 \% \mathrm{CO}_{2}$ & 1.44 & 1.78 & 2.23 & 2.93 & 3.41 & 0.109 \\
\hline $6 \% \mathrm{CO}_{2}$ & 1.44 & 2.15 & 2.97 & 3.87 & 4.67 & 0.238 \\
\hline $9 \% \mathrm{CO}_{2}$ & 1.44 & 2.98 & 3.56 & 4.32 & 5.78 & 0.135 \\
\hline $\mathrm{NaHCO}_{3}$ & 0 & 3 & 6 & 9 & 12 & \\
\hline $2.5 \mathrm{mmol} \mathrm{L}^{-1}$ & 1.44 & 1.71 & 2.23 & 2.56 & 3.26 & 0.122 \\
\hline $5.00 \mathrm{mmol} \mathrm{L}^{-1}$ & 1.44 & 1.86 & 2.66 & 3.22 & 4.43 & 0.191 \\
\hline $7.50 \mathrm{mmol} \mathrm{L}^{-1}$ & 1.44 & 1.95 & 2.98 & 3.56 & 5.88 & 0.201 \\
\hline
\end{tabular}

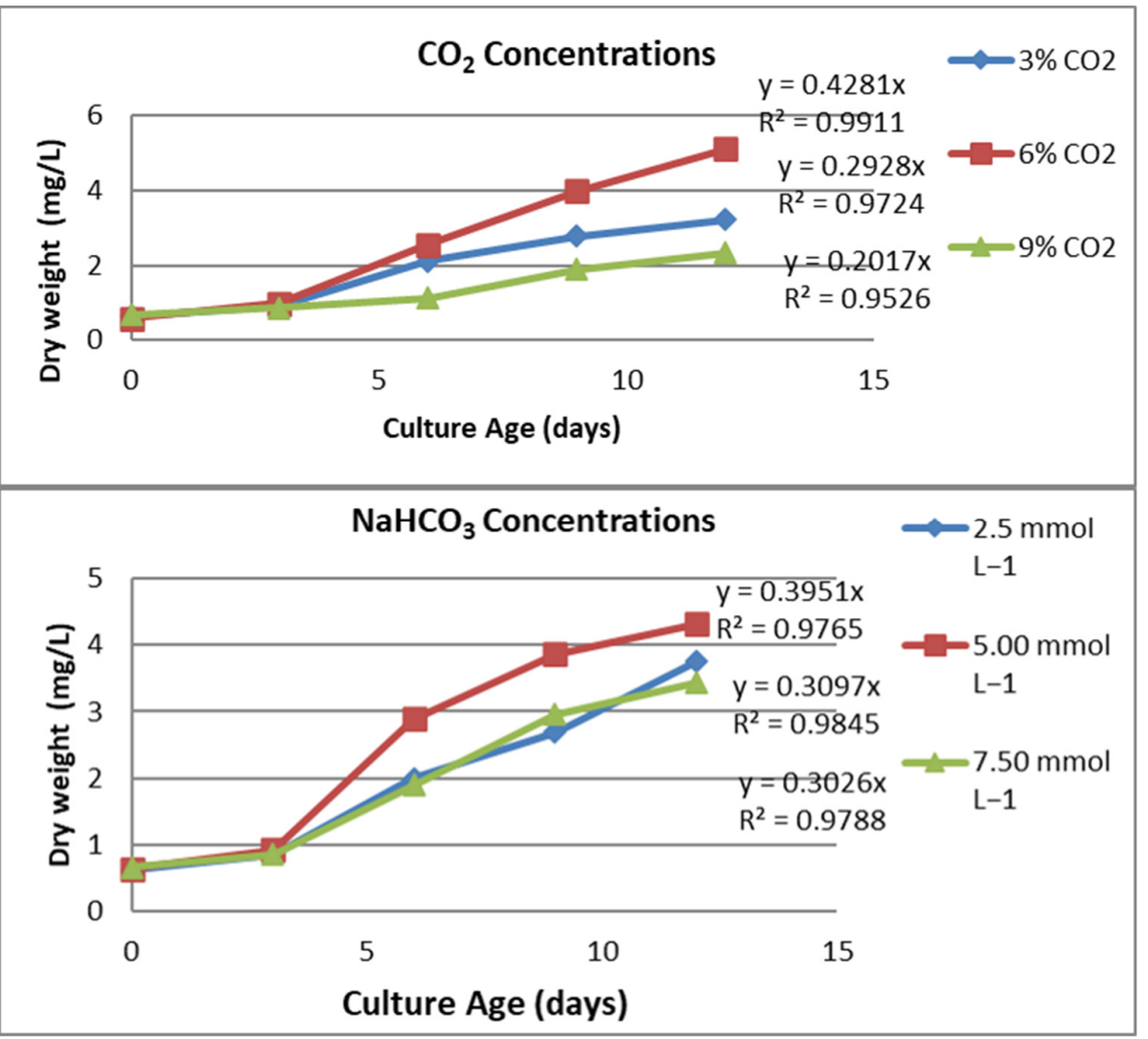

Figure 2. Impact of carbon scours and concentrations on Chlamydomonas reinhardtii biomass

Impact of the element's availability $(\mathrm{N}, \mathrm{P}, \mathrm{S})$ on C. reinhardtiigrowth and lipid contents

Sulfur, $\mathrm{N}$ and $\mathrm{P}$ elements are the most important nutrients for autotrophic growth of microalgae and their supply is central tools to microalgae biotechnology. These nutrients are playing important roles as enzyme cofactors and in photosynthetic pathways. It has been notes that many microalgae, when stressed to the sub point of growth inhibition, metabolic pathway switch to lipid accumulation (Karpagam et al., 2015), a phenomenon is interesting to researchers for production of biodiesels (Abd EL Baky and EL Baroty, 2016). 
Therefore, the availability of N, P and S (replete and deplete conditions) was assessed to accumulate high lipid contents in $C$. reinhardtii microalgae.

\section{Phosphorous (P)}

The effect of availability of P (concentrations: $1.13 \mathrm{mM}$ P-rich, PR, $0.28 \mathrm{mM}$ P-optimal, $\mathrm{PO}$ and 0.14 mM P-limited, PL) in Sueoka medium on C. reinhardtiigrowth (in term of dry weight, dw.) and lipid contents are shown in Table 3 and 4 and Figures 3 and 4 . The final dry weight and lipid contents in the different $P$ cultures were significantly deference's. The dry weight of P-rich culture was higher than in the P-optimal or Plimited $(\mathrm{p}<0.01)$. P-limited culture is yielding lowest DW than that in P-optimal or P-rich cultures. Where, high lipid content was obtained in P-Limit culture $(0.246 \mathrm{mg} / \mathrm{L})$ was than of P-optimal $(0.183 \mathrm{mg} / \mathrm{L})$ or PRich $(0.163 \mathrm{mg} / \mathrm{L})$. Although, the P-limited culture had high lipid and less DW compared to P-optimal or Prich cultures. Phosphorus starvation has lesser effects on microalgae photosynthesis in comparison to nitrogen starvation. However, phosphorus starvation is found to induce a six-fold increase in lipid production in some algae species (Goh et al., 2019).

Table 3. Impact of elements concentrations on Chlamydomonas reinhardtii biomass

\begin{tabular}{|c|c|c|c|c|c|}
\hline \multirow{2}{*}{ Elements and concentrations } & \multicolumn{5}{|c|}{ Culture Age (days) } \\
\cline { 2 - 6 } & 0 & 3 & 6 & 9 & \multicolumn{4}{c|}{} \\
\hline Nitrogen & \multicolumn{5}{|c|}{4.54} \\
\hline $7.5 \mathrm{mM} \mathrm{N}$ & 0.595 & 0.976 & 2.43 & 3.57 & 3.67 \\
\hline $3.75 \mathrm{mM} \mathrm{N}$ & 0.562 & 0.795 & 1.89 & 2.56 & 3.51 \\
\hline $1.87 \mathrm{mM} \mathrm{N}$ & 0.511 & 0.764 & 1.59 & 2.12 & 2.63 \\
\hline $0.93 \mathrm{mM} \mathrm{N}$ & 0.567 & 0.756 & 1.25 & 1.79 & 12 \\
\hline Phosphorus & 0 & 3 & 6 & 9 & 4.45 \\
\hline $1.13 \mathrm{mM} \mathrm{P}$ & 0.588 & 0.763 & 2.65 & 3.43 & 3.32 \\
\hline $0.28 \mathrm{mMP}$ & 0.654 & 0.712 & 1.76 & 1.96 & 3.83 \\
\hline $0.14 \mathrm{mM} \mathrm{P}$ & 0.674 & 0.724 & 1.54 & 2.41 & 12 \\
\hline Sulfur & 0 & 3 & 6 & 9 & 4.33 \\
\hline $0.43 \mathrm{mM} \mathrm{S}$ & 0.677 & 0.789 & 2.11 & 3.47 & 3.45 \\
\hline $0.21 \mathrm{mM} \mathrm{S}$ & 0.681 & 0.793 & 1.45 & 2.48 & 3.11 \\
\hline $0.10 \mathrm{mM} \mathrm{S}$ & 0.598 & 0.674 & 1.23 & 1.56 & \\
\hline
\end{tabular}

Table 4. Impact of nitrogen concentrations on Chlamydomonas reinhardtii oil content (\%) and oil yield

\begin{tabular}{|c|c|c|c|c|c|c|}
\hline \multicolumn{2}{|c|}{ Elements and concentrations } & \multicolumn{3}{|c|}{ Culture age (days) } & \multicolumn{2}{c|}{$\begin{array}{c}\text { Oil yield } \\
\mathrm{mg} / \mathrm{L}\end{array}$} \\
\hline Nitrogen & 0 & 3 & 6 & 9 & 12 & \\
\hline $7.5 \mathrm{mM} \mathrm{N}$ & 1.23 & 1.51 & 2.35 & 3.11 & 3.87 & 0.17 \\
\hline $3.75 \mathrm{mM} \mathrm{N}$ & 1.23 & 1.85 & 3.45 & 4.76 & 5.66 & 0.207 \\
\hline $1.87 \mathrm{mM} \mathrm{N}$ & 1.23 & 2.11 & 4.53 & 6.55 & 7.54 & 0.264 \\
\hline $0.93 \mathrm{mM} \mathrm{N}$ & 1.23 & 2.34 & 5.67 & 7.32 & 8.56 & 0.225 \\
\hline Phosphorus & 0 & 3 & 6 & 9 & 12 & \\
\hline $1.13 \mathrm{mM} \mathrm{P}$ & 1.23 & 1.57 & 1.99 & 2.65 & 3.67 & 0.163 \\
\hline $0.28 \mathrm{mMP}$ & 1.23 & 1.85 & 2.14 & 3.87 & 5.54 & 0.183 \\
\hline $0.14 \mathrm{mM} \mathrm{P}$ & 1.23 & 2.11 & 3.76 & 4.85 & 6.43 & 0.246 \\
\hline Sulfur & 0 & 3 & 6 & 9 & 12 & \\
\hline $0.43 \mathrm{mM} \mathrm{S}$ & 1.23 & 1.75 & 2.47 & 2.81 & 3.66 & 0.158 \\
\hline $0.21 \mathrm{mM} \mathrm{S}$ & 1.23 & 1.99 & 2.95 & 3.89 & 4.75 & 0.163 \\
\hline $0.10 \mathrm{mM} \mathrm{S}$ & 1.23 & 2.22 & 3.73 & 4.84 & 5.49 & 0.171 \\
\hline
\end{tabular}


Abd El Baky H and El Baroty GS (2020). Not Bot Horti Agrobo 48(3):1439-1457

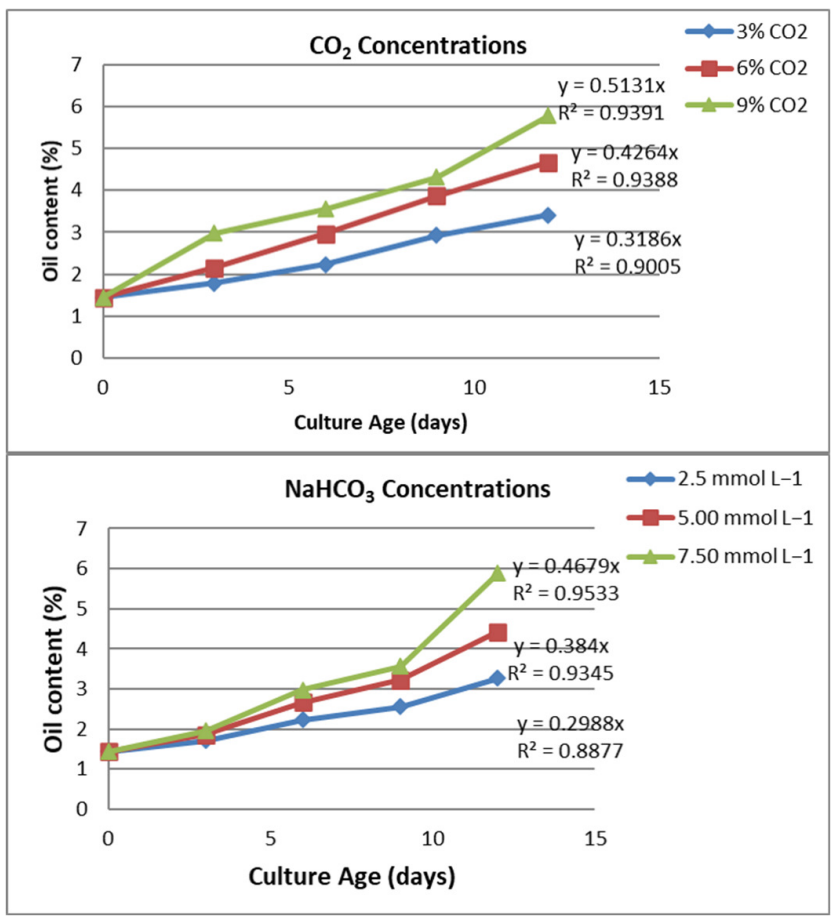

Figure 3. Impact of carbon scours and concentrations on Chlamydomonas reinhardtii oil content (\%)

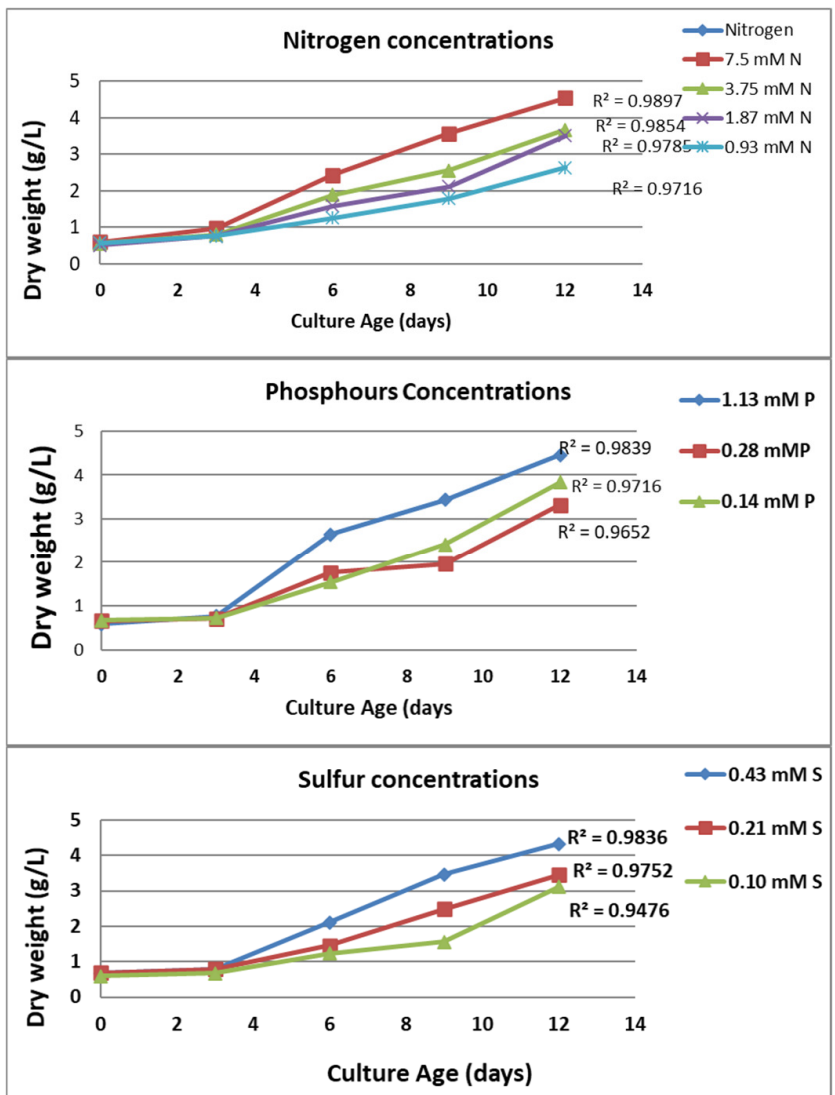

Figure 4. Impact of elements concentrations on Chlamydomonas reinhardtii biomass 


\section{Effect of $N$-concentrations on $C$. reinhardtii growth and oil yield}

Microalgae, as biological system have received considerable attention due to their high accumulation of high lipid yield when grown under $\mathrm{N}$-limited condition, which could be used for bio-fuel production (Table 4 and Figure 5). The impact of supplement of Sueoka medium by sodium nitrate as a N-source $(0.50 \mathrm{mM} \mathrm{N}$ rich, NR, $3.75 \mathrm{mM}$ N-optimal, NO, $1.78 \mathrm{mM} \mathrm{N}$-limited, NL and $0.93 \mathrm{mM} \mathrm{N}$-Sub-limited, NSL) on $C$. reinhardtii growth (in term of dry weight, dw.) are shown in Table 2 and Figure 2. The results demonstrated that the cell biomass (dw.) was increased gradually as function of incubation times. After 15 days of incubation, the biomass (mg/L) were found to be 4.54, 3.67, 3.51 and 2.62 for NR, NO, PL and SNL cultures, respectively. In regarded with total lipid contents, the negatively relation was found between $\mathrm{N}$ - concentration and lipid accumulation. The values of total lipid content ( $5 \mathrm{of} \mathrm{dw}$.) and oil yield (in parenthesis, $\mathrm{mg} / \mathrm{L}$ ) of NR, NO, PL and NSL C. reinhardtii cultured for 12 days were 3.78 (0. 17), 5.66 (0.207), 7.55 (0.264) and 8.56 (0.225), respectively. Under $\mathrm{N}$-limited condition, algae move to toward increasing of lipid biosynthesis (Abd El Baky and El Baroty, 2012). Therefore, biomass was direct proportional to $\mathrm{N}$ - concentration but TL was indirect to $\mathrm{N}$-concentration. In the most our researches we observed that phenomenon under N-limitation is a proportional reduction of dry weight due to reduce the total proteins and simultaneously inducing lipids biosynthesis due to the reduced nutrient availability (Abd El Baky et al., 2015; Abd El Baky and El Baroty 2016). Abd El Baky et al. (2012) reported that microalgae grown under Fe or $\mathrm{N}$-limitation had high carbon rich compounds due to accumulation of carbohydrates or lipids. Under nutrients stress, many microalgae have the ability to produce substantial high amounts $(20-50 \% \mathrm{dw})$ of triacylglycerols as a storage lipid (James et al., 2011; Karpagam et al., 2015).

\section{Effect of sulfur (S) concentration on C. reinhardtii growth and oil yield}

The effect of supplement of Sueoka medium by sodium sulfate as a sulfate source at different $\mathrm{S}$ concentrations (0.43 mM S-rich, SR; $0.21 \mathrm{mM} \mathrm{S-optimal,} \mathrm{SO;} \mathrm{and} 0.10 \mathrm{mM} \mathrm{S-limited,} \mathrm{SL)} \mathrm{on} \mathrm{C.} \mathrm{reinhardtii}$ growth (in term of dry weight, dw) are presented in Tables 2 and 3 and Figures 3 and 4 . The results revealed that the $C$. reinhardtii biomass ( $\mathrm{dw}$ ) was increased gradually as function of incubation period. After 12 days, the biomass $(\mathrm{mg} / \mathrm{L})$ were found to be 4.33, 3.45 and 3.11 for SR, SO and SL cultures, respectively. Also, the levels of total lipid content and oil yield (in parenthesis) were 3.66\% $(1.58 \mathrm{mg} / \mathrm{L}), 4.75 \%(0.163 \mathrm{mg} / \mathrm{L}), 5.49 \%$ and $(0.1781 \mathrm{mg} / \mathrm{L})$, respectively. Thus, afterwards, the oil content significantly increased with the decrease in $S$ levels. Previous research by Hu et al. (2008) Singh et al. (2015) using many microalgae species reported an increase in lipid productivity and lipid content when cultured under S-limited condition.

The N, P and S elements are the key factors required for microalgae growth and lipid accumulation (Abd El Baky and El Baroty, 2016). The change in N, P, and S levels led to significantly alteration of biomass (dw) and lipid contents. In rich C, N, S and P individual growth cultures, biomass may reach about two-fold, of that did in limited medium. In contrast, the values of the total lipid TL content and oil yield OY were significantly increased in all element limited of $C$. reinhardtii cultures compared with that obtained in rich or optimal cultures.

\section{Growth and lipid accumulation properties in C. reinhardtii cultured at large scale in 2000-liter photobioreactor for production biodiesel}

It is essential to optimize the nutrient growth conditions to improving the lipid accumulation without significantly biomass loss in the nutrient limited cells, which becomes a potential cost-effective strategy for keeping the production cost of biofuels at a minimum. Thus, the best possible conditions for $C$. reinhardtii growth were chosen for cultured at large-scale to improve the economic feasibility of lipid content for biodiesel production. According to above data, the explore the conditions required for accumulation high lipid content in C. reinhardtii grown under limitation availability of $(\mathrm{P}+\mathrm{N}+\mathrm{S})$ in large scale 2000-liter serial-column photobioreactor PBR. The nutrient volume, inoculums density, temperature, $\mathrm{CO}_{2}$ flow rate and levels of combined 
$\mathrm{N}, \mathrm{S} \mathrm{N}$ element levels (N-1.78 mM, P- $0.14 \mathrm{mM}$ and S-limited $0.10 \mathrm{mM}$ ) concentration was achieved to make sure the good cells grow and produce a suitable cell density and high lipid contents.
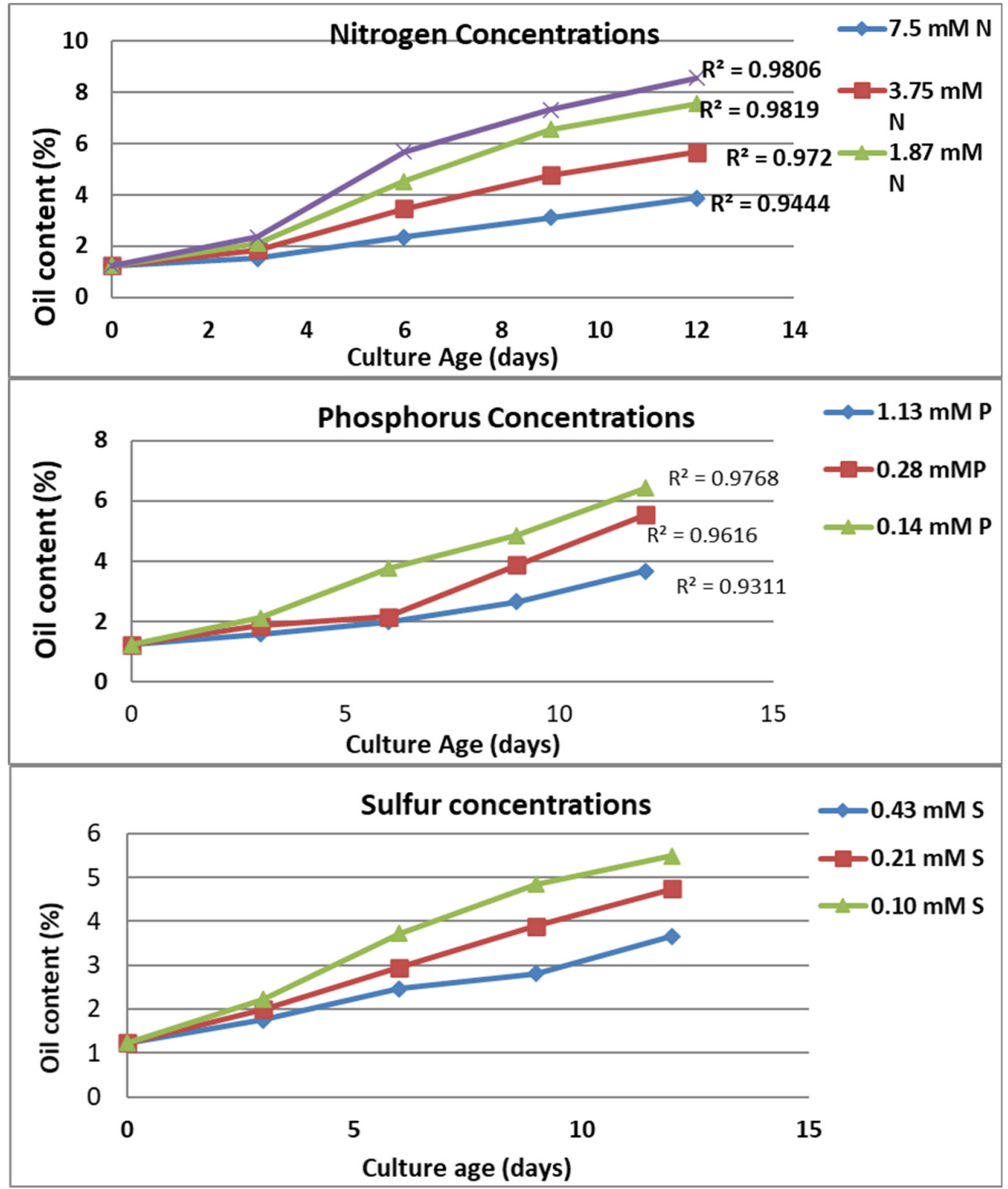

Figure 5. Impact of elements concentrations on Chlamydomonas reinhardtii oil content (\%)

After 15 days, the cultures reached the higher biomass productivity, and harvested for lipid analysis. As shows in Table 5 and Figure 6, after 15 days of cultivation, the C. reinhardtii culture, had an early stationary phase with higher growth rate, and this trend was continuously reached to 15 days of cultivation. The yield of biomass of cultures was increased gradually with varying degree during the cultivation periods. After 15 day of cultivation, the levels, of dry weight (dw.), biomass productivity, chlorophyll a (Chl a), lipid contents and oil yield $\left(\mathrm{d}^{-1}\right)$ was found to be $6.14(\mathrm{~g} / \mathrm{L}), 108.61(\mathrm{mg} / \mathrm{L}), 22.76(\%)$ and $1.22(\mathrm{~g} / \mathrm{L})$, respectively. These values were increased over all that in those induce in each basic individual concentration medium by several times, which the lipid percentage (\%) can reach to 1.7 - fold. These results showed that the induce increase lipid accumulation in $C$. reinhardtii microalgae cells were associated with values of specific growth rates of cells $(0.114 \mathrm{~g} /$ day $)$, Chla content $(31 \mathrm{mg} /$ day $)$ and OY $(0.127 \mathrm{~g} /$ day $)$ recorded under this condition. The statistical 
analysis also revealed that good correlation was found between the $\mathrm{dw}$ as factor of microalgae growth and the incubation time with $\left(R^{2}\right.$ of $\left.0.9778, y=0.2681 \mathrm{x}+0.9751\right)$. These results are confirmed by these previous reports that the $C$. reinhardtii microalga, showed that the metabolic effect of limitation $\mathrm{P}, \mathrm{N}$ and $S$, related to the increasing lipid accumulation and also may causes cell growth inhibition and decreases the total biomass. (Hu et al., 2008; Griffiths and Harrison, 2009). As already previously described by Abd El Baky and El Baroty (2014, 2016, 2017), that the nutrient limitation decreases partially the biomass yield and enhance accumulation of lipid content in microalgae cells due to the metabolism shift from synthesis of protein and other $\mathrm{N}$ biomolecular to synthesis of neutral lipid molecules (e.g., triacylglycerols and carotenoids). However, the increased lipid productivity is reflecting the independent impact of $\mathrm{N}$ or $\mathrm{P}$ levels on both growth and lipid contents (Sajjadi et al., 2018). Abd El Baky and El Baroty (2016) reported that the cultivation conditions of microalgae including nitrogen, sulfur, phosphate and $\mathrm{CO}_{2}$ concentrations and light intensity had a high influenced impact on cell growth and lipid accumulation.

\section{Oil yield (g/L)}

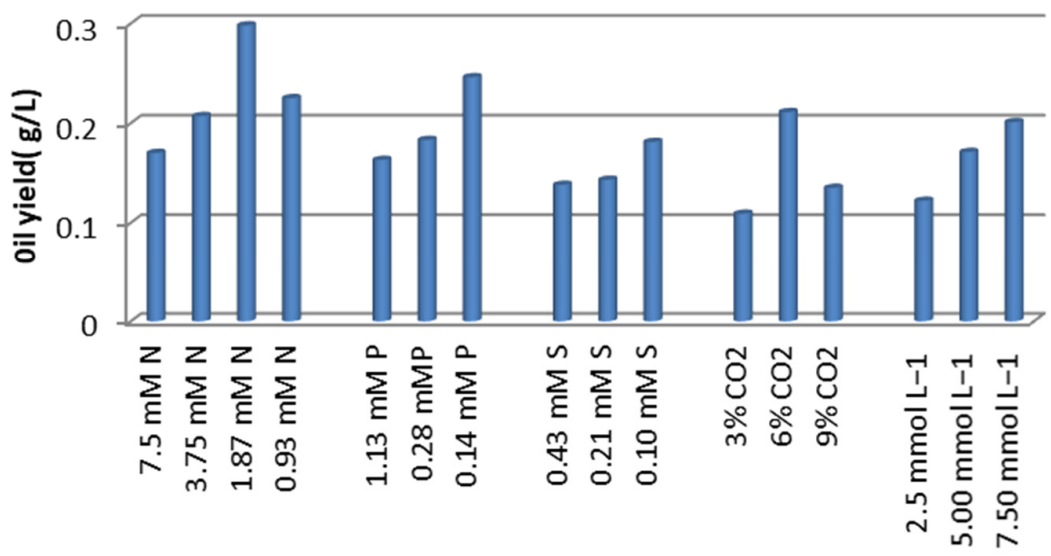

Elements concentrations

Figure 6. Oil yield of Chlamydomonas reinhardtii grown under different element concentrations

Table 5. Specific growth rate (SGR g/day) of cell, chlorophyll a (chll-a) and lipid of Chlamydomonas reinhardtii grown in nitrogen $\left(1.87 \mathrm{mM} \mathrm{L}^{-1} \mathrm{~N}\right)$, Phosphorus $\left(0.14 \mathrm{mM} \mathrm{L}^{-1} \mathrm{P}\right)$ and sulfur $\left(0.10 \mathrm{mM} \mathrm{L}^{-1} \mathrm{~S}\right)$ limitation and $\mathrm{CO}_{2}(6 \%)$

\begin{tabular}{|c|c|}
\hline Parameters & Chlamydomonas reinhardtii \\
\hline SGR of cell (g/day) & 0.114 \\
\hline SGR of Chll-a (g/day) & 0.278 \\
\hline SGR of lipid (g/day) & 0.0127 \\
\hline
\end{tabular}

Physical-chemical properties (PCP) of oils

The lipid of $C$. reinhardtii grows in limited of $(\mathrm{N}+\mathrm{P}+\mathrm{S})$ medium in PBR allowed to producing high lipid accumulation. Table 6, showed some physicochemical properties of $C$. reinhardtii lipid includes: refractive index $\left(1.55 \pm 0.11\right.$, at $\left.40{ }^{\circ} \mathrm{C}\right)$, viscosity $\left(\mathrm{mm}^{2} / \mathrm{S}\right)$, density $\left(\mathrm{g} / \mathrm{cm}^{3} 24{ }^{\circ} \mathrm{C}\right)$, saponification value (SV185.54 $\pm 2.48 \mathrm{mg}$ of $\mathrm{KOH} / \mathrm{g}$ of oil), acid value (AV, $0.43 \pm 0.037 \mathrm{mg}$ of $\mathrm{KOH} /$ one gram of oil), iodine value (IV 75.9 $\pm 0.55 \mathrm{mg}$ of $\mathrm{I}_{2} / 100 \mathrm{~g}$ of oil), peroxide value (PV $0.376 \pm 0.034 \mathrm{meq}_{2} \mathrm{~kg}^{-1}$ ). These values showed that $C$. reinhardtiil lipid is suitable for produce biodiesel production, that are similar to those reported for plant oils like soybean, palm and rapeseed crops that are suitable for biodiesel production the most restrictive biodiesel standards, i.e. the EN 14214 and STAM D 6571 (Giakoumis, 2013). 
Abd El Baky H and El Baroty GS (2020). Not Bot Horti Agrobo 48(3):1439-1457

Table 6. Physicochemical properties of Chlamydomonas reinhardtii oils

\begin{tabular}{|c|c|}
\hline Physiochemical properties & Chlamydomonas reinhardtii oil properties \\
\hline Molecular weight $(\mathrm{Da})$ & 929 \\
\hline Refractive index $\left(40^{\circ} \mathrm{C}\right)$ & $1.55 \pm 0.11$ \\
\hline Viscosity $\left(\mathrm{mm}^{2} / \mathrm{S}\right)$ & $6.87 \pm 0.45$ \\
\hline Density $\left(\mathrm{g} / \mathrm{cm}^{3}\right) 24^{\circ} \mathrm{C}$ & $1.54 \pm 0.14$ \\
\hline Saponification value ( $\mathrm{mg} \mathrm{KOH} \mathrm{g}^{-1}$ oil) & $185.54 \pm 2.48$ \\
\hline Acidity (mg KOH / g oil) & $4.43 \pm 0.37$ \\
\hline Iodine value (mg of $\mathrm{I} / 100 \mathrm{~g}$ of oil) & $75.9 \pm 0.55$ \\
\hline Peroxide value meq $\mathrm{O}_{2} / \mathrm{kg}$ oil & $0.01 \pm 0.001$ \\
\hline Conjugated diene $\left(\mathrm{g}^{1 \%} 1 \mathrm{~cm}(\lambda 232)\right.$ & 0.01 \\
\hline Conjugated triene $(\mathrm{e} 1 \% 1 \mathrm{~cm}(\chi 270)$ & 0.01 \\
\hline
\end{tabular}

Biodiesel production from C. reinhardtiilipids

According to our previous work (Abd EL Baky and El Baroty, 2016), the direct transesterification TE reaction condition was optimizated as a way to improve the biodiesel yield. In this study, microalgae biomass of $C$. reinhardtii cultured at large scales in limited combinations of $(\mathrm{N}+\mathrm{S}+\mathrm{P})$ medium was subjected to a directly TE in one step. The biodiesel yield (BY \%) and biodiesel productivity $\left(\mathrm{mg}^{-1} \mathrm{~L}^{-1} \mathrm{~d}^{-1}\right)$ were found to be was about $87.96 \%$ and $1.67 \pm 0.23$, respectively (Table 7 ).

Table 7. Chlamydomonas reinhardtii cultivation under high lipids production conditions at large scale tubular photobioreactor

\begin{tabular}{|c|c|}
\hline Parameters & $\begin{array}{c}\text { Chlamydomonas } \\
\text { reinhardtii }\end{array}$ \\
\hline Biomass productivity $\left(\mathrm{g}^{-1} \mathrm{~L}^{-1} \mathrm{~d}^{-1}\right)$ & $0.15 \pm 0.012$ \\
\hline Specific growth rate $\mu\left(\mathrm{d}^{-1}\right)$ & 0.298 \\
\hline $\mathrm{R}^{2}$ & $\mathrm{R}^{2}=0.9759$ \\
\hline Max. lipids contents $(\mathrm{w} / \mathrm{w} \%)$ & 22.76 \\
\hline Max. lipids productivity $\left(\mathrm{mg}^{-1} \mathrm{~L}^{-1} \mathrm{~d}^{-1}\right)$ & $1.9 \pm 0.35$ \\
\hline $\mathrm{R}^{2}$ & $\mathrm{R}^{2}=0.9338$ \\
\hline Max. biodiesel contents $(\mathrm{w} / \mathrm{w} \%)$ & 87.96 \\
\hline Max. biodiesel productivity $\left(\mathrm{mg}^{-1} \mathrm{~L}^{-1} \mathrm{~d}^{-1}\right)$ & $1.67 \pm 0.23$ \\
\hline
\end{tabular}

The FAME profile of $C$. reinhardtii biodiesel

The FAME profile (FAME, fatty acids methyl esters) of $C$. reinhardtii biodiesel was analyzed by GC/MS methods. The data shows that the main fatty acids were long-chain fatty acids with 16 and 18 carbon atoms, including palamitic acid (C16:0), oleic acid (C18:1) and linoleic acid (C18:2). Other FA, including myristic acid (C14:0), stearic acid (C18:0), linolenic acid ( $\gamma$-C18:3), pentadecanoic (C15:0) were percent in significant quantity. The FA composition of $C$. reinhardtii was similar to the crop seed oils compositions, considered as a potential source for biodiesel production, which have noticeably high C16 saturated (SFA $36.97 \%$ TFAs) and C18:1 (27.33\%, of TFAs) of fatty acids (Table 8). This observation in C. reinhardtii biodiesel was quite similar to that found in previous works, where the palamitic acid and oleic were identified as a major FAs in most species of microalgae (El Kassas, 2013; Abd EL Baky et al., 2014, 2015). James et al. (2011) demonstrated that $C$. reinhardtii starch mutants had high levels of 16:0,18:1, 18:2 and low levels of long chain fatty acids (20:0, 20:1, 20:2, 22:0, and 24:0), when nitrogen starved, which may be suitable for conversion to liquid fuels. Abd El Baky et al. $(2012,2014)$ reported that microalgae grown in $\mathrm{N}$ and P-limited condition, had a higher level of unsaturated fatty acids than that in cells grow on nutrient sufficient medium. However, N-stress has been found to decrease the saturated fatty acid of C16:0, which could improve the 
Cetane number and oxidative stability of the biodiesel produced (Sajjadi et al., 2018). However, total polyunsaturated fatty acids (TPUFA) in microalgae culture were percent in lower quantity. The values of TFAs and TSFAs were a direct proportion with ratios of saturated FA/ unSFA/ (unsaturation degree DU), oxidation degree (OR) (Table 9). The C. reinhardtii had a moderate $\mathrm{Du}$ (1.21), TU/TS (1.69) and OR (8.33) degrees as that recorded in some microalgae biodiesel. However, the lipid composition has considerable impact on the technology of biodiesel production and product quality (Demirbas, 2009). In general C. reinhardtii had a high SFA and MUSFA, in a good balance, which lead to a good oxidative stability and low-temperature properties and promotes the quality of biodiesel.

Table 8. Fatty acid methyl esters profile of Chlamydomonas reinhardtii biodiesel

\begin{tabular}{|c|c|}
\hline \multirow{2}{*}{ Molecular formula } & Chlamydomonas reinhardtii biodiesel \\
\cline { 2 - 2 } & Relative fatty acids content \% \\
\hline $\mathrm{C}_{14: 0}$ & $\ldots \ldots$. \\
\hline $\mathrm{C}_{15: 0}$ & $\ldots \ldots$. \\
\hline $\mathrm{C}_{16: 0}$ & 33.76 \\
\hline $\mathrm{C}_{16: 19 \mathrm{c}}$ & 4.68 \\
\hline $\mathrm{C}_{16: 27,10 \mathrm{c}}$ & 1.99 \\
\hline $\mathrm{C}_{16: 37,10 \mathrm{c}}$ & 2.43 \\
\hline $\mathrm{C}_{16: 47,10 \mathrm{c}}$ & 2.36 \\
\hline $\mathrm{C}_{17: 0}$ & $\ldots \ldots$. \\
\hline $\mathrm{C}_{18: 0}$ & 3.21 \\
\hline $\mathrm{C}_{18: 1(9 c)}$ & 20.32 \\
\hline $\mathrm{C}_{18: 2(9,12 \mathrm{c})}$ & 14.94 \\
\hline $\mathrm{C}_{18: 3(6,9,12 \mathrm{c})}$ & 9.54 \\
\hline $\mathrm{C}_{18: 4(5,9,12,15 \mathrm{c})}$ & 3.72 \\
\hline $\mathrm{C}_{20: 1}$ & 1.11 \\
\hline $\mathrm{C}_{22: 1}$ & 1.22 \\
\hline
\end{tabular}

a: Fatty acid was identified based on the retention time of standard fatty acids and MS spectra

b: The percentage of the fatty acid was evaluated through the peak area.

Table 9. Evaluation criteria of Chlamydomonas reinhardtii biodiesel

\begin{tabular}{|c|c|}
\hline Lipid criteria (\%) & Chlamydomonas reinhardtii biodiesel \\
\hline Total saturated fatty acids & 36.97 \\
\hline Total monounsaturated fatty acids & 27.33 \\
\hline Total polyunsaturated fatty acids & 34.98 \\
\hline Total unsaturated fatty acids & 62.31 \\
\hline TU/TS & 1.69 \\
\hline DU & 1.21 \\
\hline RO & 8.33 \\
\hline
\end{tabular}

TU/TS: Total unsaturated / Total saturated

DU: Degree of Unsaturated: TMSFA $/ 100+2[\mathrm{Tdi}=\mathrm{FA} / 100]+3[\mathrm{~T}$ Tri $=$ FA $/ 100]+4[$ Tetra $(\mathrm{x}) \mathrm{FA} / 100]$

RO: Rate of oxidation $=[\%$ UFA $1=x 1 / 100]+\mathrm{T}$ di $(\mathrm{x}) \mathrm{FA} / 100]+\mathrm{T}$ trii $(\mathrm{x}) \mathrm{FA} / 100]+[\% \mathrm{UFA} 4(\mathrm{x}) 50 / 100]$

$(\mathrm{x})=$ Number of double pounds 


\section{The biodiesel properties of $C$. reinhardtii}

Biodiesel (FAME) properties derived $C$. reinhardtii lipid cultured at large scales PBR on combined limited $(\mathrm{N}+\mathrm{P}+\mathrm{S})$ nutrient levels ( Table 10$)$ including the density $\left(0.871 \pm 0.12 \mathrm{Kg}^{-1} \mathrm{~L}\right)$, viscosity $(4.14 \pm 0.23$ $\mathrm{mm}^{2} \mathrm{~S}^{-1}$, at $40{ }^{\circ} \mathrm{C}$ ), acid value (AV $0.45 \pm 0.01 \mathrm{mg} \mathrm{KOH} /$ one gram oil), peroxide value (PV less than $0.1 \mathrm{meqO}_{2}$ $\mathrm{kg}-1$ of oil), saponification value ( $\mathrm{SV}, 189.33 \pm 1.79 \mathrm{mg}$ of $\mathrm{KOH} / 100 \mathrm{~g})$, iodine value (IV, $\mathrm{g} \mathrm{I}_{2} / 100 \mathrm{~g}$ ) were determined. Also, the cetane number (CN 64.8), oxidation ability (OX 0.344) and degree of unsaturation (DU 97.29) were calculated based on empirical equations extracted from the GC/MS fatty acid profile (Table 6). All chosen parameter was found to be within that limit values reported in the international standards, EN 14214 and ASTM D6751 for biodiesel and agree with that findings in the literatures for biomass biodiesel (Kaisan et al., 2015). Moreover, the biodiesel had low values of conjugated diene $\left(\mathrm{g}^{1 \%} 1 \mathrm{~cm}\right.$ absorbance $\mathrm{A}=0.01$ at $\lambda 232 \mathrm{~nm}$ was 0.1$)$ and conjugated triene $\left(\mathrm{g}^{1 \%} 1 \mathrm{~cm} A=0.01\right.$ at $\lambda 270 \mathrm{~nm}$ was 0.1$)$ which indicating good quality of biodiesel due to the high oxidative stability (against auto oxidation reaction) and high shelf life time. Further, the ratio of SFA and unsaturated fatty acids are tented to produce optimal heating value (HV) and high $\mathrm{CN}(\mathrm{min}$ ) that is related to the shorter ignition delay time (Moser 2014). On the other hand, other quality checking parameters (based on empirical equations) of biodiesel like average of molecular weight (mw, Da 999), heating value ( $\mathrm{HV}, 41.36 \mathrm{MJ} / \mathrm{kg})$, flash point $\left(\mathrm{FP}, 44.0^{\circ} \mathrm{C}\right)$, LCSF 33.33 and CFPP 88.23 were found to be appropriate as per the given in international standard (Nascimento et al., 2013. Thus, the results the $C$. reinhardtii biodiesel property was found in accordance with the biodiesel specifications are given by the most international standards (ASTM D6751 US and EN 14214 Europe (Hoekman et al., 2012). Also, all those properties of $C$. reinhardtii biodiesels are similar to that reported in literatures for plant oils and some microalgae and macroalgae species used for production of high biodiesel quality (Moser, 2009; Ramos et al., 2009; Demirbas, 2011; Abd El Baky and El Baroty, 2016, 2015). Thus, this result indicates that lipids of microalgae grow under limited $(\mathrm{S}+\mathrm{P}+\mathrm{N})$ condition have a high potential as economical feedstock for biodiesel production, due to the fact that limited nutrient can reduce the essential nutrients consumption and it could make the production of $C$. reinhardtii lipid is feasible and as a promising strategy.

Table 10. Comparison of physiochemical properties of Chlamydomonas reinhardtii biodiesel, diesel fuel and biodiesel standard

\begin{tabular}{|c|c|c|c|c|}
\hline Property & Units & $\begin{array}{c}\text { Biodiesel of } \\
\text { Chlamydomonas } \\
\text { reinhardtii }\end{array}$ & $\begin{array}{l}\text { Diesel }^{\mathrm{a}} \\
\text { fuel }\end{array}$ & $\begin{array}{c}\text { ASTM }^{\text {a }} \\
\text { biodiesel standard }\end{array}$ \\
\hline Density & $\left(\mathrm{Kg}^{-1} \mathrm{~L}\right)$ & $0.871 \pm 0.12$ & 0.838 & $0.86-0.9$ \\
\hline Viscosity & $\mathrm{mm}^{2} \mathrm{~S}^{-1}$, at $40^{\circ} \mathrm{C}$ & $4.14 \pm 0.23$ & $1.9-4.1$ & $3.5-5.0$ \\
\hline Acid value (AV) & $\mathrm{mg} \mathrm{KOH}^{-1} \mathrm{~g}$ & $0.45 \pm 0.01$ & Max 0.5 & Max 0.5 \\
\hline Peroxide number & meq $\mathrm{O}_{2} / \mathrm{kg}$ oil & $\mathrm{ND}$ & $\mathrm{ND}$ & \\
\hline Saponification value (SV) & $\mathrm{mg} \mathrm{KOH} \mathrm{g}^{-1}$ oil & $189.33 \pm 1.79$ & $\ldots .$. & .......... \\
\hline Iodine value & $\mathrm{g} \mathrm{I}_{2} / 100 \mathrm{~g}$ & $45.78 \pm 2.96$ & 120 & Max 120 \\
\hline Cetane number (CN min) & & 64.8 & 45.9 & $\geq 47$ \\
\hline Oxidizability (OX) & & 0.344 & ....... & $>0.7$ \\
\hline DU & & 97.29 & ....... & ....... \\
\hline Heating value & $(\mathrm{MJ} / \mathrm{kg}) \mathrm{HV}$ & 41.36 & & \\
\hline Flash point $(\mathrm{FP})$ & $\left({ }^{\circ} \mathrm{C}\right)$ & 44.00 & & 93 \\
\hline LCSF & & 33.33 & & $\ldots .$. \\
\hline CFPP & & 88.23 & & ....... \\
\hline
\end{tabular}

a: The data about diesel and ASTM biodiesel standard were taken from published literature; DU $=$ MUFA $+(2 \mathrm{X}$ PUSFA); $\mathrm{CN}=(46.3+[5458 / \mathrm{SV}])-(0.225 \mathrm{X} \mathrm{IV}) ;$ Oxidizability $(\mathrm{OX})=[0.02(\%$ Oleic $)+\%$ linoleic +2 (\%linolenic $)]$ $/ 100 ; \mathrm{HHV}=0.4625 v+39.450$, Higher Heating Value of biodiesel from their viscosity $(v) ; \mathrm{FP}=(\mathrm{HHV}-32.12)$ /0.21; $\mathrm{LCSF}=\left(0.1 \mathrm{X} \mathrm{C}_{16}\right)+\left(0.5 \mathrm{XC}_{18}\right)+\left(1 \mathrm{XC}_{20}\right)+\left(1.5 \mathrm{XC}_{22}\right)+\left(2 \mathrm{XC}_{24}\right) ; \mathrm{CFPP}=(3.1417 \mathrm{X} \mathrm{LCSF})-16.477$ 


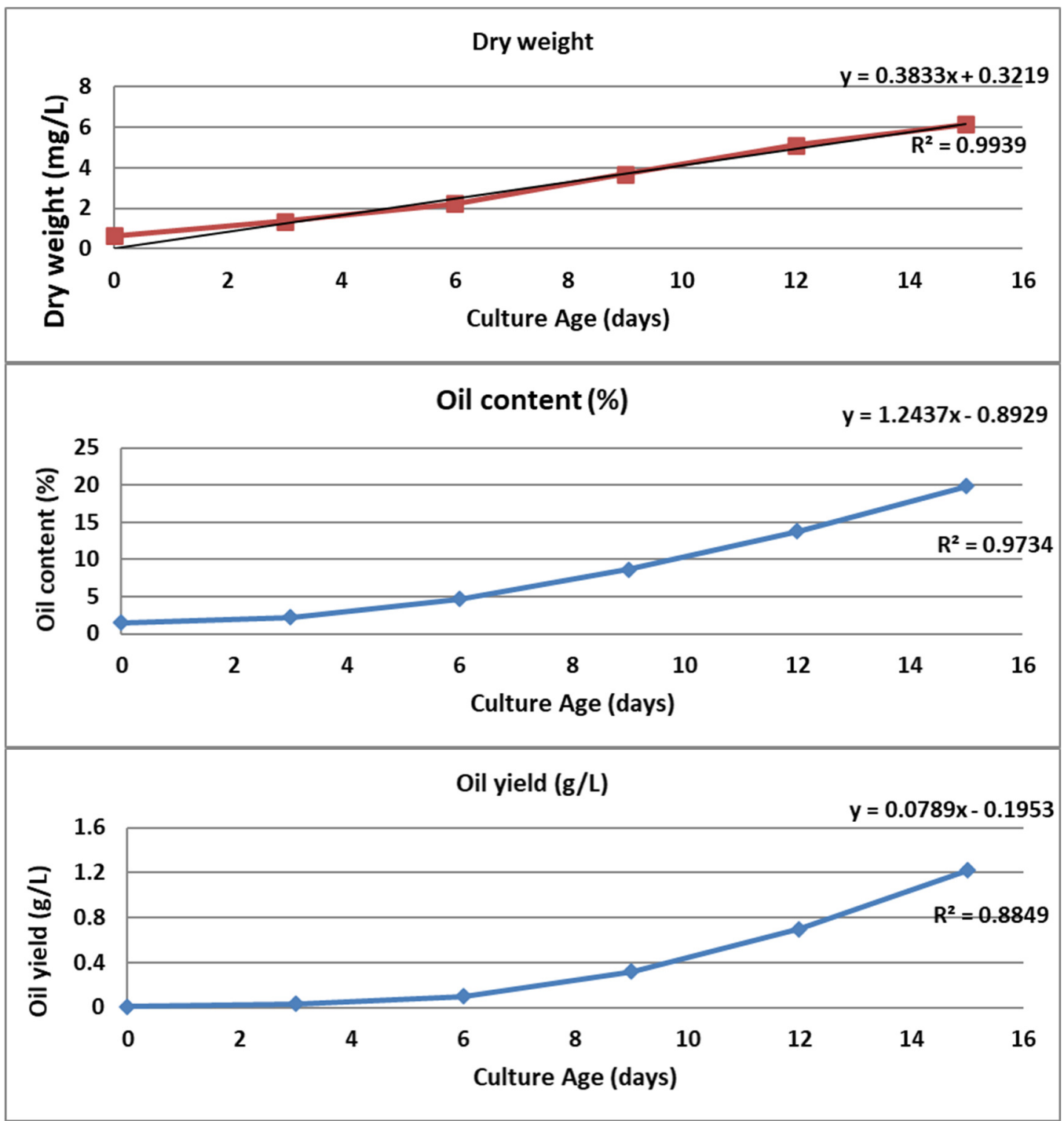

Figure 7. Dry weight, oil content and oil yield of Chlamydomonas reinhardtii grown in photobioreactor under nitrogen, phosphorus and sulfur limitation

\section{Conclusions}

The study demonstrated feasibility of lipid production from C. reinhardtii cultivation modes, among which limited viability of combined elements $\mathrm{S}+\mathrm{P}+\mathrm{N}$ condition under large scale PBR (2000 Liters) cultured, as the effect strategy for the lipid accumulation. Thus, it is insight to C. reinhardtii strain thought for costeffective biofuels production. The $C$. reinhardtii lipid was subjected to acidic TE process for producing the biodiesel. The GC/MS analysis of fatty acids presented in the biodiesel showed a predominance of mono unsaturated and saturated fatty acids, considered ideal for the production of high-quality biodiesel. The properties of biodiesel were in accordance with international specification established by EN 14214 and ASTM 6571. However, this study may assess the importance and helps to cover the gap of the microalgae cultivated in Egypt for biodiesel production and other application. 


\section{Acknowledgements}

This work was financially supported by The Science and Technology Development Fund (STDF) with a grand project ID number of 10428 (Egypt).

\section{Conflict of Interests}

The authors declare that there are no conflicts of interest related to this article.

\section{References}

Abd El Baky HH, El Baroty GS, Bouaid A, Mercedes M, Aracil J (2012). Enhancement of lipid accumulation in Scenedesmus obliquus by optimizing $\mathrm{CO}_{2}$ and $\mathrm{Fe}^{3+}$ levels for biodiesel production. Bioresource Technology 119: 429-432. https://doi.org/10.1016/j.biortech.2012.05.104

Abd El Baky HH, El-Baroty GS (2013). The potential use of microalgal carotenoids as dietary supplements and natural preservative ingredient. Journal of Aquatic Food Product Technology 4:392-406. https://doi.org/10.1080/10498850.2011.654381

Abd El Baky HH, El-Baroty GS (2016). Potential of macroalgae Ulva lactuca L as a source feedstock for biodiesel production. Recent Patents on Food, Nutrition \& Agriculture 8(3):199-204. https://doi.org/10.2174/2212798409666170602080725

Abd El Baky HH, El-Baroty GS, Bouaid A (2014). Lipid induction in Dunaliella salina culture aerated with various levels $\mathrm{CO}_{2}$ and its biodiesel production. Journal of Aquaculture Research and Development 5:1-6. https://doi.org/10.4172/2155-9546.1000223

Abd El Baky HH, El-Baroty GS, Ibrahem AE (2015). Functional characters evaluation of biscuits sublimated with pure phycocyanin isolated from Spirulina and Spirulina biomass. Nutricion Hospitalaria 32(1):231-241

American Oil Chemists' Society (2004). Official Methods and Recommended Practices of the AOCS, 5th ed.; AOCS Press: Boulder, CO, USA.

Benvenuti G, Bosma R, Cuaresma M, Janssen M, Barbosa, MJ, Wijffels RH (2015). Selecting microalgae with high lipid productivity and photosynthetic activity under nitrogen starvation. Journal of Applied Phycology 27(4):14251431. https://doi.org/10.1007/s10811-014-0470-8

Cesar AD, Conejero MA, Ribeiro EC, Batalha MA (2019). Competitiveness analysis of "social soybeans" in biodiesel production in Brazil. Renewable Energy 133:1147-1157.

Davey MP, Alison G, Smith AG, Horst I, Duong G, Tomsett BV, ... Howe CG (2014). Triacylglyceride production and autophagous responses in Chlamydomonas reinhardtii depend on resource allocation and carbon source. Eukaryotic Cell 13 (3):392-400. https://doi.org/10.1128/EC.00178-13

Demirbas A (2009). Progress and recent trends in biodiesel fuels. Energy Conversion and Management 50:14-34. https://doi.org/10.1016/j.enconman.2008.09.001

Demirbas A (2011). Biodiesel from oilgae, biofixation of carbon dioxide by microalgae: a solution to pollution problems. Applied Energy 88:3541-3547. https://doi.org/10.1016/j.apenergy.2010.12.050

El-Kassas HY (2013). Growth and fatty acid profile of the marine microalga Picochlorum Sp. grown under nutrient stress conditions. Egyptian Journal of Aquatic Research 39:233-239. http://dx.doi.org/10.1016/j.ejar.2013.12.007

Fan LH, Zhang YT, Zhang L, Chen HL (2008). Evaluation of a membrane-sparged helical tubular photobioreactor for carbon dioxide biofixation by Chlorella vulgaris. Journal of Membrane Science 325:336-345. https://doi.org/10.1016/j.memsci.2008.07.044

Giakoumis EG (2013). A statistical investigation of biodiesel physical and chemical properties, and their correlation with the degree of unsaturation. Renewable Energy 50:858-878. https://doi.org/10.1016/j.renene.2012.07.040

Goh BH, Ong HC, Cheah MY, Chen W, Yu KL Mahlia TM (2019) Sustainability of direct biodiesel synthesis from microalgae biomass: A critical review. Renewable and Sustainable Energy Reviews 107:59-74. https://doi.org/10.1016/j.rser.2019.02.012 
Griffiths MJ, Harrison ST (2009). Lipid productivity as a key characteristic for choosing algal species for biodiesel production. Journal of Applied Phycology 21:493-507. https://doi.org/10.1007/s10811-008-9392-7.

Hoekman SK, Broch A, Robbins C, Ceniceros E, Natarajan M (2012). Review of biodiesel composition, properties, and specifications. Renewable and Sustainable Energy Reviews 16:143-169. http://dx.doi.org/10.1016/j.rser.2011.07.143

Hu Q, Sommerfeld M, Jarvis E, Ghirardi M, Posewitz M, Seibert M, Darzins A (2008). Microalgal triacylglycerols as feedstocks for biofuel production: perspectives and advances. Plant Journal 54:621-639. https://doi.org/10.1111/j.1365-313X.2008.03492.x

James GO, Hocart CH, Hillier W, Chen H, Kordbacheh F, Price D, Djordjevic MA (2011). Fatty acid profiling of Chlamydomonas reinhardtii under nitrogen deprivation. Bioresource Technology 102:3343-3351. https://doi.org/10.1016/j.biortech.2010.11.051

Juergens MT, Disbrow B, Shachar-Hill Y (2016). The relationship of triacylglycerol and starch accumulation to carbon and energy flows during nutrient deprivation in Chlamydomonas reinhardtii, Plant Physiology 171:2445-2457. https://doi.org/10.1104/pp.16.00761

Kaisan MU, Pam GY, Kulla DM, Kehinde AJ (2015). Effects of oil extraction method on biodiesel production from wild grape seeds: a case study of Soxhlet extraction method and mechanical press engine driven expeller method. STM - Journal of Alternate Energy and Technologies 6(1):35-41.

Karpagam R, Preeti R, Ashokkumar B, Varalakshmi P (2015). Enhancement of lipid production and fatty acid profiling in Chlamydomonas reinhardtii, CC1010 for biodiesel production. Ecotoxicology and Environmental Safety 121:253-257. https://doi.org/10.1016/j.ecoenv.2015.03.015

Kropat J, Hong-Hermesdorf A, Casero D, Ent P, Castruita M, Pellegrini M, Merchant SS, Malasarn D (2011) A revised mineral supplement increase biomass and growth rate in Chlamydomonas reinhardtii. Plant Journal 66:770-780. https://doi.org/10.1111/j.1365-313X.2011.04537.x

Lam MK, Lee KT (2014). Cultivation of Chlorella vulgaris in a pilot-scale sequential baffled column photobioreactor for biomass and biodiesel production. Energy Conversion and Management 88:399-410.

Lee S, Kim TY (2017). Performance and emission characteristics of a DI diesel engine operated with diesel/DEE blended fuel. Applied Thermal Engineering 121:454-461. https://doi.org/10.1016/j.applthermaleng.,04.112

Lichtenthaler HK, Wellburn AR (1983). Determinations of total carotenoids and chlorophyll a and b in leaf extracts in different solvents. Biochemical Society Transactions 11:591-592. https://doi.org/10.1042/bst0110591

Ma Y, Gao Z, Wang Q, Liu Y (2018). Biodiesels from microbial oils: Opportunity and challenges. Bioresource Technology 263:631-641. https://doi.org/10.1016/j.biortech.2018.05.028

Martins AA, Marques F, Cameira M, Santos E, Sara B, Costa L, ... Mata TM (2018). Water footprint of microalgae cultivation in photobioreactor. Energy Procedia 153:426-443. https://doi.org/10.1016/j.egypro.2018.10.031

Mathimani T, Mallick N (2018). A comprehensive review on harvesting of microalgae for biodiesel - Key challenges and future directions. Renewable and Sustainable Energy Reviews 91:1103-1120. https://doi.org/10.1016/j.rser.2018.04.083

Moser B (2009). Biodiesel production, properties, and feedstocks. In Vitro Cellular and Developmental Biology 45:229266.

Moser BR (2014). Impact of fatty ester composition on low temperature properties of biodiesel-petroleum diesel blends. Fuel 115:500-506.

Nascimento IA, Marques SSI, Cabanelas ITD, Pereira SA, Druzian JI, De Souza CO, ... Nascimento MA (2013). Screening microalgae strains for biodiesel production: Lipid productivity and estimation of fuel quality based on fatty acid profiles as selective criteria. Bioenergy Research 6:1-13.

Patel A, Arora N, Mehtani J, Pruthi V, Pruthi PA (2017). Assessment of fuel properties on the basis of fatty acid profiles of oleaginous yeast for potential biodiesel production. Renewable and Sustainable Energy Reviews 77 604-616. https://doi.org/10.1016/j.rser.2017.04.016

Ramos MJ, Fernández CM, Casas A, Rodríguez L, Pérez A (2009). Influence of fatty acid composition of raw materials on biodiesel properties. Bioresource Technology 100(1):261-268. http://dx.doi.org/10.1016/j.biortech.2008.06.039

Sajjadi B, Chen W, Raman AA, Ibrahim S (2018). Microalgae lipid and biomass for biofuel production: A comprehensive review on lipid enhancement strategies and their effects on fatty acid composition. Renewable and Sustainable Energy Reviews 97:200-232. https://doi.org/10.1016/j.rser.2018.07.050 
Singh P, Guldhe A, Kumari S, Rawat I, Bux F (2015). Investigation of combined effect of nitrogen, phosphorus and iron on lipid productivity of microalgae Ankistrodesmus falcatus KJ671624 using response surface methodology. Biochemical Engineering Journal 94:22-29. https://doi.org/10.1016/j.bej.2014.10.019

Singh TS, Verma TN, Nashine P, Shijagurumayum C (2018). BS-III diesel vehicles in imphal, India: an emission perspective. In: Sharma N, Agarwal A, Eastwood P, Gupta T, Singh A (Eds). Air Pollution and Control. Energy, Environment, and Sustainability. Springer, Singapore, 978-981-10-7184-3. https://doi.org/10.1007/978-98110-7185-0_5

Sueoka N, Chiang, KS, Kates JR (1967). Deoxyribonucleic acid replication in meiosis of Chlamydomonas reinhardtii. Isotopic transfer experiments with a strain producing eight zoospores. Journal of Molecular Biology 25:44-67. https://doi.org/10.1016/0022-2836(67)90278-1

Sun LY, Cui WJ, Chen KM (2018). Two Mychonastes isolated from freshwater bodies are novel potential feedstocks for biodiesel production. Energy sources, Part A: Recovery, utilization, and environmental effects 40(12):1452-1460. https://doi.org/10.1080/15567036.2018.1477869

Tang D, Han W, Li P, Miao X, Zhong J (2009). CO 2 biofixation and fatty acid composition of Scenedesmus obliquus and Chlorella pyrenoidosa in response to different $\mathrm{CO}_{2}$ levels. Bioresource Technology 102(3):3071-3076. https://doi.org/10.1016/j.biortech.2010.10.047

Wang Y, Yu J, Wang P, Deng S, Chang J, Ran Z (2018). Response of energy microalgae Chlamydomonas reinhardtiito to nitrogen and phosphors stress. Environmental Science and Pollution Research 25(6):5762-5770. https://doi.org/10.1007/s11356-017-0931-0

Wang ZT, Ullrich, N, Joo, S, Waffenschmidt S, Goodenough U. (2009) Algal lipid bodies. Stress induction, purification, and biochemical characterization in wild-type and starchless Chlamydomonas reinhardtii. Eukaryotic Cell 8:1856-1868. https://doi.org/10.1128/EC.00272-09

Wu H, Miao X (2014). Biodiesel quality and biochemical changes of microalgae Chlorella pyrenoidosa and Scenedesmus obliquus in response to nitrate levels. Bioresource Technology 170:421-427. https://doi.org/10.1016/j.biortech.2014.08.017

Zhang L, Wang N, Yang M, Ding K, Yong-Zhong Wang Y, Huo D, Hou C (2019). Lipid accumulation and biodiesel quality of Chlorella pyrenoidosa under oxidative stress induced by nutrient regimes. Renewable Energy 143:17821790. https://doi.org/10.1016/j.renene.2019.05.081
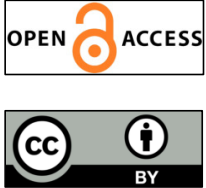

The journal offers free, immediate, and unrestricted access to peer-reviewed research and scholarly work. Users are allowed to read, download, copy, distribute, print, search, or link to the full texts of the articles, or use them for any other lawful purpose, without asking prior permission from the publisher or the author.

License - Articles published in Notulae Botanicae Horti Agrobotanici Cluj-Napoca are Open-Access, distributed under the terms and conditions of the Creative Commons Attribution (CC BY 4.0) License. (C) Articles by the authors; UASVM, Cluj-Napoca, Romania. The journal allows the author(s) to hold the copyright/to retain publishing rights without restriction. 